\title{
Sugar Protectants Improve the Thermotolerance and Biocontrol Efficacy of the Biocontrol Yeast, Candida oleophila
}

\begin{abstract}
Fangliang Zheng ${ }^{1}$, Weiwei Zhang ${ }^{1}$, Yuan Sui ${ }^{2 *}$, Ruihan Ding ${ }^{1}$, Wenfu Yi', Yuanyuan $\mathrm{Hu}^{1}$, Hongsheng Liu' ${ }^{1}$ and Chunyu Zhu ${ }^{1 *}$
\end{abstract}

'School of Life Science, Liaoning University, Shenyang, China, ${ }^{2}$ Chongqing Key Laboratory of Economic Plant Biotechnology, Institute of Special Plants, Chongqing University of Arts and Sciences, Yongchuan, China

A variety of sugar compounds have been used as additives to protect various biocontrol yeasts from adverse environmental stresses. However, studies on maltose and lactose as sugar protectants are limited, and their protective effect is not clear. In the present study, exposure of the biocontrol yeast Candida oleophila cells to $45^{\circ} \mathrm{C}$ for $10 \mathrm{~min}$, while immersed in either 5 or $10 \%(\mathrm{w} / \mathrm{v})$ maltose or lactose, provided a significant protective effect. The addition of maltose and lactose significantly enhanced enzyme activity and gene expression of catalase, thioredoxin reductase, and glutathione reductase, relative to cells that have been immersed in sterile distilled water (controls) exposed to $45^{\circ} \mathrm{C}$. In addition, C. oleophila cells suspended in maltose and lactose solutions also exhibited higher viability and ATP levels, relative to control cells. Notably, the biocontrol efficacy of C. oleophila against postharvest diseases of apple fruit was maintained after the yeast was exposed to the high temperature treatment while immersed in maltose and lactose solutions. These results demonstrate the potential of maltose and lactose as sugar protectants for biocontrol agent against heat stress.

Keywords: antioxidant enzyme, biocontrol yeast, gene expression, sugar protectants, thermotolerance

\section{INTRODUCTION}

Postharvest losses in apples from gray mold (Botrytis cinerea), blue mold (Penicillium expansum), and Alternaria rot (Alternaria alternata) are an ongoing problem (Romanazzi et al., 2016; Vilanova et al., 2017; Kim et al., 2018). Due to concerns about the health hazards of traditional postharvest fungicides, the use of postharvest biocontrol agents has been widely explored (Droby et al., 2009; Liu et al., 2013a; Spadaro and Droby, 2016). Biocontrol efficacy of the antagonists after application, however, is affected by various environmental conditions, including high temperature, salt stress, and oxidative stress (Ippolito and Nigro, 2000; Liu et al., 2011a, 2012; Sui et al., 2015; Cheng et al., 2016; Wang et al., 2018). In order to enhance the survival and performance of antagonistic yeasts exposed to adverse abiotic stresses, the addition of sugar protectants such as trehalose, fructose, lactose sucrose, galactose, and glucose (Abadias et al., 2001; Li and Tian, 2006; Melin et al., 2007; Sui and Liu, 2014) has been explored. The beneficial effect of specific sugar 
protectants, however, may be specific to each species of biocontrol agent. Therefore, there is a need to better understand the mechanism underlying the protective effect.

Sugars as protectants have been extensively studied. Maltose is a sugar protectant that is also used as a nutrient in yeast culture broth (Gientka et al., 2016). Lactose is a type of disaccharide that is present in mammalian milk (Chen and Gänzle, 2017). Maltose and lactose have a relatively low cost, which makes them ideal for use as a protectant additive in the formulation of yeast biocontrol products or the actual use of yeast biocontrol agents in commercial settings. Importantly, however, little research has been conducted on the use of these compounds as protectants of antagonistic yeast against adverse environmental conditions.

Candida oleophila is a yeast, whose postharvest biocontrol activity has been well-documented (Liu et al., 2012, 2013b; Wang et al., 2018). It can be applied to apple fruit before and after harvest for the management of postharvest pathogens such as $B$. cinerea, $P$. expansum, and $A$. alternata. The survival rate of C. oleophila is dramatically reduced, however, over $40^{\circ} \mathrm{C}$ (Liu et al., 2012). In response to high temperature stress, the level of reactive oxygen species (ROS) in yeast cells like Saccharomyces cerevisiae and Pichia guilliermondii rapidly accumulates, and oxidative damage of the mitochondria results in a significant decrease in intracellular ATP content, cell viability, and ultimately, yeast survival (Kim et al., 2013; Sui and Liu, 2014). The present study was conducted to determine: 1) the protective effect of maltose and lactose on C. oleophila exposed to lethal high temperature stress $\left.\left(45^{\circ} \mathrm{C}, 10 \mathrm{~min}\right) ; 2\right)$ the effect of these sugars on gene expression and enzyme activity of the antioxidant enzymes, catalase (CAT), thioredoxin reductase (TrxR), and glutathione reductase (GR); 3) changes in intracellular ATP levels in response to the sugars and temperature stress; 4) the biocontrol efficacy of $C$. oleophila against gray mold (B. cinerea), blue mold ( $P$. expansum), and Alternaria rot (A. alternata) of apple after the yeast had been immersed in the sugar solution and exposed to a lethal, heat stress $\left(45^{\circ} \mathrm{C}, 10 \mathrm{~min}\right)$.

\section{MATERIALS AND METHODS}

\section{Yeast Strain}

The biocontrol yeast C. oleophila (strain I-182) was isolated from the surface of tomato fruit (Wilson et al., 1993). It was obtained from Dr. Michael Wisniewski at USDA-ARS-Appalachian Fruit Research Station, USA. About $100 \mathrm{ml}$ of yeast peptone glucose (YPD) broth (10 g yeast extract, $20 \mathrm{~g}$ peptone, and $20 \mathrm{~g}$ glucose in $1,000 \mathrm{ml}$ water) was prepared in a $300 \mathrm{ml}$ Erlenmeyer flask and inoculated with $C$. oleophila to obtain an initial concentration of $1 \times 10^{5}$ cells $/ \mathrm{ml}$. Yeast cultures were incubated at $25^{\circ} \mathrm{C}$ on a rotary shaker at $200 \mathrm{rpm}$ for $16 \mathrm{~h}$, at which time the cultures have reached the medium index phase, with an OD value of 0.7 .

\section{Fungal Pathogens}

The fungal pathogens, $B$. cinerea (CGMCC3.3790), P. expansum (CGMCC3.3703), and A. alternata (CGMCC3.15529), were obtained from China General Microbiological Culture Collection Center (CGMCC) and maintained on potato dextrose agar (PDA). To reactivate the culture and verify their pathogenicity, each pathogen was inoculated into wounded apple fruit and re-isolated onto PDA, once an infection was established. Spore suspensions of either B. cinerea, $P$. expansum, or $A$. alternata were obtained from 2 -week-old PDA cultures grown at $25^{\circ} \mathrm{C}$. Final spore concentrations were determined using a hemocytometer and adjusted to $10^{4}$ cells $/ \mathrm{ml}$ with sterile distilled water.

\section{Fruit}

Apple fruits were harvested at commercial maturity. Fruits without wounds or rot were selected based on the uniformity of size. The selected fruits were disinfected with $2 \%(\mathrm{v} / \mathrm{v})$ sodium hypochlorite for $2 \mathrm{~min}$, rinsed with tap water, and air-dried prior to their use in the biocontrol assays.

\section{Heat Treatment of Yeast Suspensions}

Yeast cells were pelleted by centrifugation at $8,000 \mathrm{~g}$ for $3 \mathrm{~min}$ and washed three times with sterile distilled water to remove residual medium. Aliquots of the aqueous cell suspension were transferred to a conical flask $(50 \mathrm{ml})$ containing 5 or $10 \%$ solutions $(\mathrm{w} / \mathrm{v})$ of either maltose or lactose to obtain a final concentration of $1 \times 10^{8}$ cells $/ \mathrm{ml}$. A culture flask containing sterile water and $1 \times 10^{8}$ yeast cells $/ \mathrm{ml}$ was used as a control. All of the flasks were incubated in a $45^{\circ} \mathrm{C}$ water bath and manually shaken for $10 \mathrm{~min}$. Immediately after the treatment, the treated yeast cells were then cooled by incubating the flasks in a $25^{\circ} \mathrm{C}$ water bath.

\section{Viability Assay}

The sugar solution was removed from the treated samples by pelleting the cells. Subsequently, the cells were resuspended in sterile water and adjusted to a concentration of $1 \times 10^{8}$ cells $/ \mathrm{ml}$. The cells were then dilution plated on YPDA (YPD, $20 \mathrm{~g}$ agar per well). Petri plates were incubated at $25^{\circ} \mathrm{C}$ for $12 \mathrm{~h}$, and cell viability was expressed as a percentage of colony forming units (CFU) relative to untreated cells. There were three replicates in each treatment, and each experiment was repeated three times.

\section{RNA Isolation and Reverse Transcription-Quantitative PCR (RT-qPCR) Analysis of Gene Expression}

Total RNA was extracted from each of the samples of treated yeast cells (water, maltose, or lactose at 5 and $10 \%(\mathrm{w} / \mathrm{v})$ exposed to $45^{\circ} \mathrm{C}$ for $\left.10 \mathrm{~min}\right)$. The total RNA extracts were treated with DNase and then purified using an EasyPure RNA Kit (TransGen Biotech, Beijing, China) according to the manufacturer's instructions. Total RNA was then reverse transcribed into cDNA using TranScript One-Step gDNA Removal and cDNA Synthesis SuperMix (TransGen Biotech, Beijing, China). RT-qPCR analysis was conducted using GoTaq $^{\circledR}$ qPCR Master Mix kit (Promega, Madison, Wisconsin, USA). A qTOWER 2.2 (Analytik Jena AG, Germany) 
thermocycler was set to the following cycle: $94^{\circ} \mathrm{C}$ for $30 \mathrm{~s}$, $94^{\circ} \mathrm{C}$ for $5 \mathrm{~s}, 58 / 59 / 60^{\circ} \mathrm{C}$ for $15 \mathrm{~s}, 72^{\circ} \mathrm{C}$ for $10 \mathrm{~s}, 40$ cycles. The expression level of three target genes, CAT, $\operatorname{Tr} x R$, and $G R$, was analyzed using gene-specific primers (Table 1). The resulting data were normalized to a reference gene, $18 \mathrm{~S} r \mathrm{RNA}$ (Liu et al., 2012). The $2^{-\triangle \Delta C T}$ method was used to calculate relative expression (Livak and Schmittgen, 2001). At the end of each PCR reaction, melting curve analyses of the amplification products were performed to ensure that unique products were amplified. PCR products were cloned and sequenced to verify their identity. The RT-qPCR analyses consisted of three independent biological replicates and three technical replicates per treatment, and the experiment was repeated three times.

\section{Assay of Enzyme Activity}

Extracts from treated yeast cells for the enzyme activity assay of the antioxidant enzymes, CAT, GR, and TrxR, were prepared as described in the previous studies (Cheng et al., 2016; Wang et al., 2018). Untreated yeast cells (not immersed in a sugar solution) were used as a control. Cells were disrupted in liquid nitrogen and suspended in cold potassium phosphate buffer (0.1 M, pH 7.0). The cell homogenate was centrifuged at $10,000 \mathrm{~g}$ for $20 \mathrm{~min}$ at $4^{\circ} \mathrm{C}$, and the resulting supernatant was used in each of the enzyme assays. The enzyme activity of CAT, TrxR, and GR was measured using commercial assay kits (Nanjing Institute of Bioengineering, Nanjing, China), and expressed as $\mathrm{U}$ per $\mathrm{mg}$ protein. Protein content was measured using a Bradford assay (Bradford, 1976) with bovine serum albumin as a standard. One unit of CAT activity was defined as the decomposition of $1 \mu \mathrm{M} \mathrm{H}_{2} \mathrm{O}_{2}$ per second in the reaction system. One unit of TrxR activity was defined as the deoxidation of $1 \mathrm{nM}$ DTNB per min at $25^{\circ} \mathrm{C}$. One unit of GR activity was defined as the amount necessary to decompose $1 \mathrm{mM}$ of $\mathrm{NADPH}$ as a substrate per min. Assays of each treatment consisted of three independent biological replicates and the experiment was repeated three times.

\section{ATP Levels}

The ATP assay was performed as described in a previous study (Li et al., 2010). ATP in C. oleophila cells (approximately $20 \mathrm{mg}$ of fresh weight) was extracted with $50 \mu \mathrm{l}$ of $2.5 \%$ trichloroacetic acid (TCA) for $3 \mathrm{~h}$ at $4^{\circ} \mathrm{C}$. After centrifugation at $10,000 \mathrm{~g}$

TABLE 1 | Gene-specific primers used in RT-qPCR analysis of gene expression.

\begin{tabular}{|c|c|c|c|c|}
\hline $\begin{array}{l}\text { Gene } \\
\text { name }\end{array}$ & $\begin{array}{l}\text { NCBI } \\
\text { accession } \\
\text { no. }\end{array}$ & Primer sequence & $\begin{array}{c}\text { Annealing } \\
\text { temp. } \\
\left({ }^{\circ} \mathrm{C}\right)\end{array}$ & $\begin{array}{l}\text { Product } \\
\text { size } \\
\text { (bp) }\end{array}$ \\
\hline CAT & JN615130 & $\begin{array}{l}\text { F: AAGGGTTCAGGTGCTTACGG } \\
\text { R: GCAGAACCGTITCACCACC }\end{array}$ & 59 & 140 \\
\hline $\operatorname{Tr} \times R$ & JN615133 & $\begin{array}{l}\text { F: TATCACCACCGATGCCGTTG } \\
\text { R: ACATGCAGAGTCACCACCAC }\end{array}$ & 60 & 175 \\
\hline GR & JN615135 & $\begin{array}{l}\text { F: CATTGCTGCCGGACGTAGAT } \\
\text { R: ATAGATCCGGCTTCTGGGTG }\end{array}$ & 58 & 123 \\
\hline $\begin{array}{l}18 S \\
\text { rRNA }\end{array}$ & AB013534 & $\begin{array}{l}\text { F: ATTGGAGGGCAAGTCTGGTG } \\
\text { R: AGAAGGAAAGGCTCGGTTGG }\end{array}$ & 159/60 & 156 \\
\hline
\end{tabular}

for $15 \mathrm{~min}, 10 \mu \mathrm{l}$ of the resulting supernatant was diluted with $115 \mu \mathrm{l}$ of ATP-free $\mathrm{H}_{2} \mathrm{O}$ and $125 \mu \mathrm{l}$ of ATP-free Trisacetate buffer $(40 \mathrm{mM}, \mathrm{pH}$ 8.0). ATP content was determined using a luciferin/luciferase kit (ENLITEN ${ }^{\circledR}$ ATP Assay System, Promega, USA) according to the manufacturer instructions. Luminescence emission was determined using a multi-mode microplate reader. The assay of each treatment sample consisted of three, independent biological replicates, and the experiment was repeated three times.

\section{Biocontrol Assay}

The biocontrol efficacy of $C$. oleophila against gray mold (B. cinerea), blue mold ( $P$. expansum), and Alternaria rot (A. alternata) was evaluated. Three wounds $(4 \mathrm{~mm}$ deep $\times$ $3 \mathrm{~mm}$ wide) were made on the equator of each fruit with a sterile nail. A $10 \mu \mathrm{l}$ suspension $\left(1 \times 10^{7}\right.$ cells $\left./ \mathrm{ml}\right)$ of maltosetreated, lactose-treated, or non-sugar-treated C. oleophila yeast cells that have been exposed to $45^{\circ} \mathrm{C}$ for $10 \mathrm{~min}$ was pipetted into each wound. Sterile distilled water served as one control, while $10 \mu$ suspension $\left(1 \times 10^{7}\right.$ cells $\left./ \mathrm{ml}\right)$ of fresh yeast cells not exposed to sugar and high temperature served as a second control. All the yeast suspensions applied into wounds were made in sterile distilled water. The yeast-treated fruits were separated into three groups. After the fruits were air-dried for $2 \mathrm{~h}, 10 \mu \mathrm{l}$ of a $B$. cinerea suspension $\left(1 \times 10^{4}\right.$ spores $\left./ \mathrm{ml}\right)$ was inoculated into each wound of the first group, $10 \mu \mathrm{l}$ of a $P$. expansum suspension $\left(1 \times 10^{4}\right.$ spores $\left./ \mathrm{ml}\right)$ was inoculated into each wound of the second group, and $10 \mu \mathrm{l}$ of a A. alternata suspension $\left(1 \times 10^{4}\right.$ spores $\left./ \mathrm{ml}\right)$ was inoculated into each wound of the third group. Treated fruits were placed in a covered plastic food tray, and each tray was enclosed with a polyethylene bag and stored at $25^{\circ} \mathrm{C}$. Disease incidence and lesion diameter on each apple were determined after 4 days. Incidence represented the percentage of infected wounds, while lesion diameter was measured only on those wounds that were infected. Each treatment contained three replicates with 10 fruits each, and the experiment was repeated three times.

\section{Data Analysis}

All statistical analyses were performed using SPSS version 20.0 (SPSS Inc., Chicago, IL, USA). Data with a single variable (treatment) were analyzed using one-way ANOVA, and mean separations were performed using a Duncan's multiple range test. Differences at $p<0.05$ were considered as significant. Data presented in this article were pooled across three independent repeated experiments, as the interaction between treatment and experiment variables was not significant.

\section{RESULTS}

\section{Effect of Maltose and Lactose on Thermotolerance of C. oleophila}

The survival rate of $C$. oleophila in the control samples after exposure to $45^{\circ} \mathrm{C}$ for $10 \mathrm{~min}$ was approximately $42 \%$ (Figure 1). 


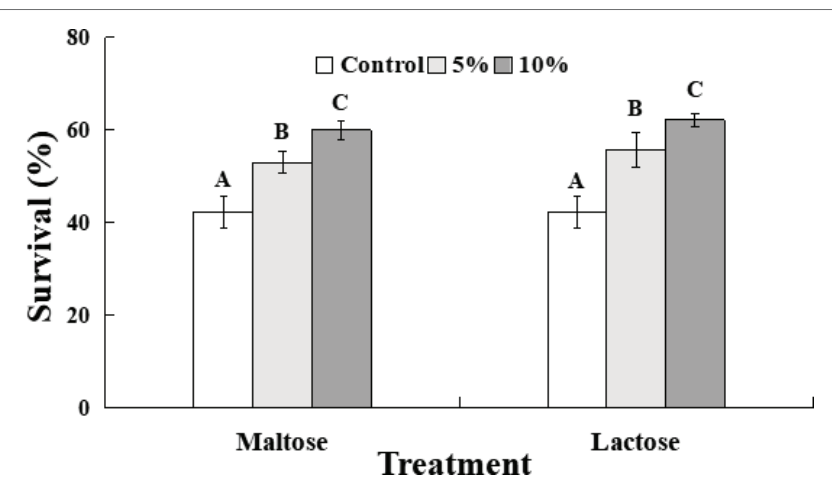

FIGURE 1 | Percent survival of $C$. oleophila cells suspended in water (control), or 5 and $10 \%(\mathrm{w} / \mathrm{v})$ maltose or lactose and exposed to $45^{\circ} \mathrm{C}$ for $10 \mathrm{~min}$. Error bars represent standard deviations of the means. Data represent the mean \pm standard deviation of three independent experiments, where each experiment consisted of three biological replicates $(n=9)$. Columns with different letters are significantly different according to a Duncan's multiple range test at $p<0.05$.

The survival rate of yeast cells immersed in either the 5 or $10 \%$ maltose or lactose sugar solutions, however, was significantly increased. The survival rate in the $10 \%$ sugar treatments was approximately $60 \%$, which was approximately $10 \%$ higher than it was in the $5 \%$ sugar treatments, where the survival rate was approximately $50 \%$.

\section{Gene Expression in Response to the Heat Treatment}

In general, exposure to heat stress significantly increased gene expression of CAT and GR (Control vs. Time 0, before heat treatment). The expression of CAT (Figure 2A) and $\operatorname{Tr} x R$ (Figure 2B) exhibited in a similar fashion. Gene expression in the control group, 5\% sugar treatment, and 10\% sugar treatment increased in a stepwise manner, respectively; with the expression of CAT in the $10 \%$ lactose treatment being about 10 times greater than in the control and 5\% lactose treatment cells. On the other hand, the expression in the $10 \%$ maltose treatment cells was significantly greater than in the control cells. The expression of GR (Figure 2C) also increased significantly in response to being immersed in the sugar protectants. GR expression in the $10 \%$ maltose treatment was approximately five times greater than in the 5\% maltose treatment, while the expression in the 5\% lactose treatment and $10 \%$ lactose treatment cells was basically similar and was significantly greater than in the control yeast cells.

\section{Antioxidant Enzyme Activity}

As indicated in Figure 3, exposure to heat stress significantly increased the activity of all the three enzymes, CAT, TrxR, and GR (Control vs. Time 0, before heat treatment). CAT enzyme activity in response to the heat treatment was significantly greater in the yeast cells that had been immersed in the sugar solutions than it was in the control cells that

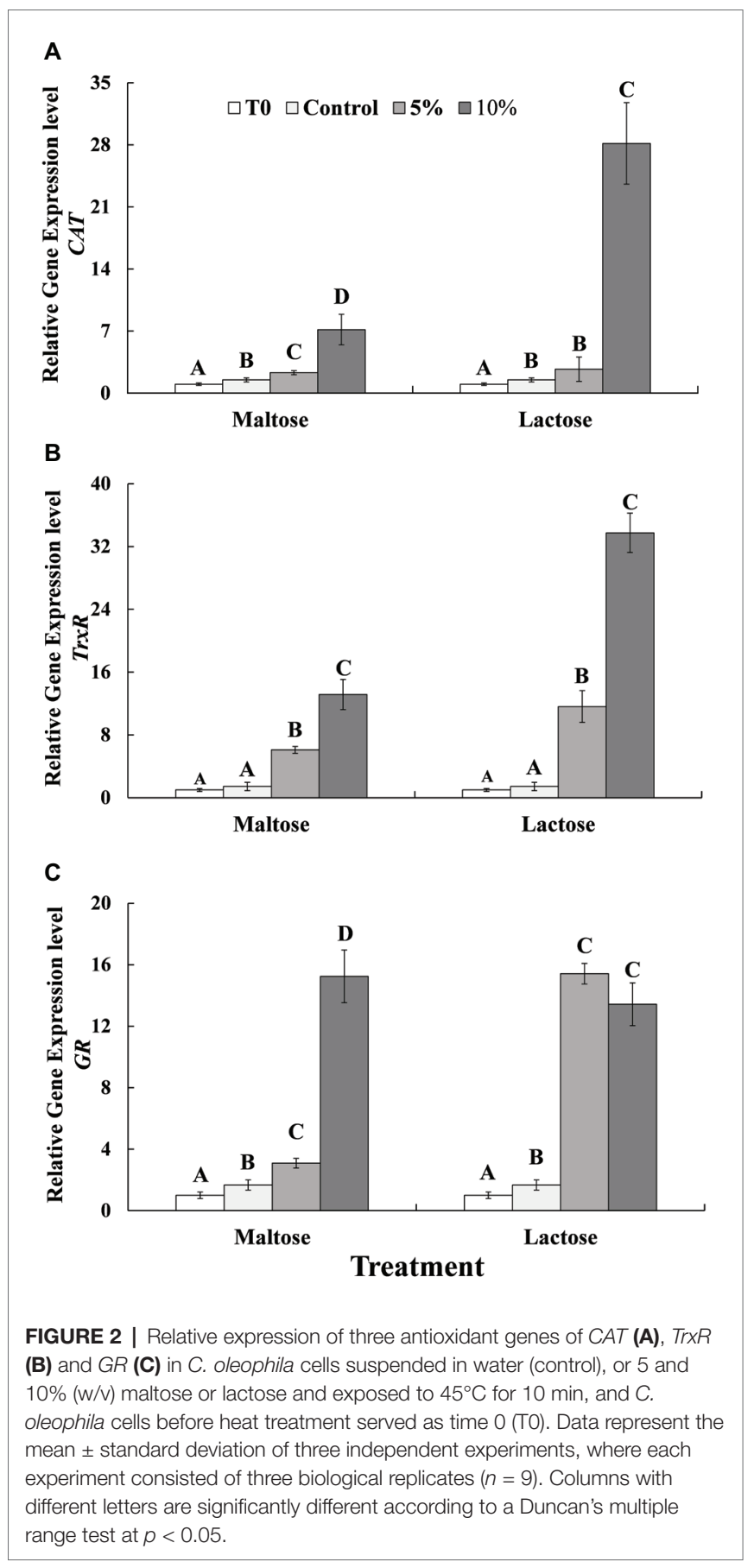

had been immersed in distilled water (Figure 3A). CAT enzyme activity was also significantly greater in the $10 \%$ maltose treatment than it was in the $5 \%$ maltose treatment. In contrast, CAT activity in the 5 and $10 \%$ lactose treatments was similar, though still twice the level than CAT activity in the control cells. TrxR (Figure 3B) and GR (Figure 3C) activities in cells of the $5 \%$ maltose treatment were approximately twice that of the control. TrxR and GR activities in the 10\% maltose treatment were even higher than they were in the 

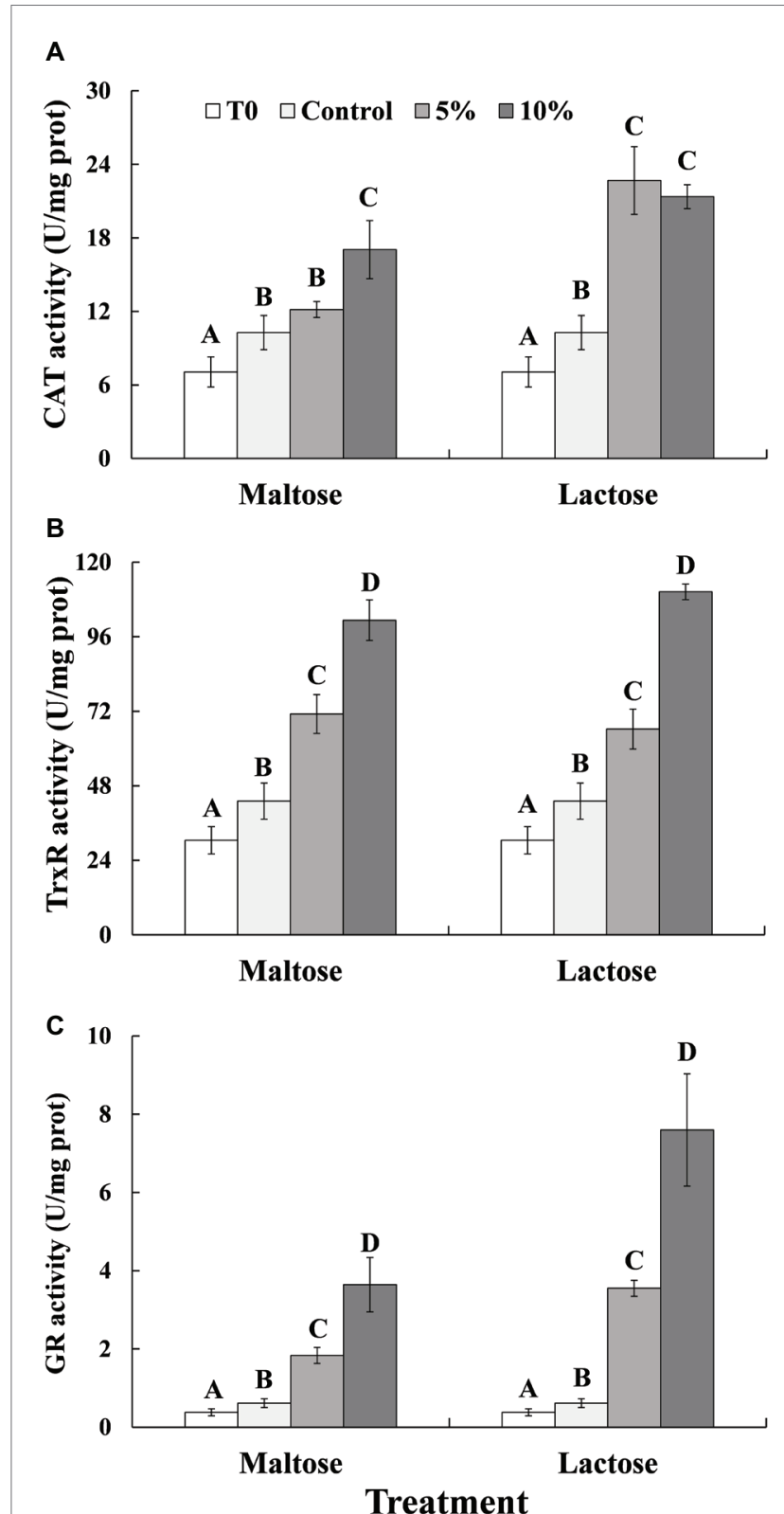

FIGURE 3 | CAT (A), TrXR (B), and GR (C) activity in C. oleophila cells suspended in water (control), or 5 and $10 \%(\mathrm{w} / \mathrm{v})$ maltose or lactose and exposed to $45^{\circ} \mathrm{C}$ for $10 \mathrm{~min}$, and $\mathrm{C}$. oleophila cells before heat treatment served as time 0 (TO). Data represent the mean \pm standard deviation of three independent experiments, where each experiment consisted of three biological replicates $(n=9)$. Columns with different letters are significantly different according to a Duncan's multiple range test at $p<0.05$.

$5 \%$ maltose treatment and also significantly higher than the control treatment. In the $10 \%$ lactose treatment, TrxR activity was over double of the activity in the control. GR activity in $10 \%$ lactose treatment was approximately seven times greater than in the control treatment, about twice the level than $5 \%$ lactose treatment.

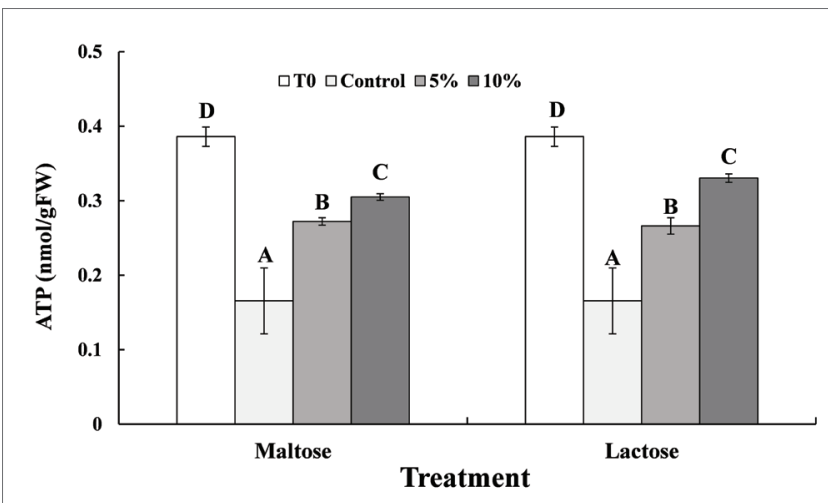

FIGURE 4 | ATP levels measured in in C. oleophila cells suspended in water (control), or 5 and $10 \%(\mathrm{~W} / \mathrm{v})$ maltose or lactose and exposed to $45^{\circ} \mathrm{C}$ for $10 \mathrm{~min}$, and $\mathrm{C}$. oleophila cells before heat treatment served as time 0 (TO). Data represent the mean \pm standard deviation of three independent experiments, where each experiment consisted of three biological replicates $(n=9)$. Columns with different letters are significantly different according to a Duncan's multiple range test at $p<0.05$.

\section{ATP Levels of C. oleophila in Response to High Temperature}

ATP levels in C. oleophila cells immersed in the different sugar solutions before (Time 0) and after exposure to the high temperature treatment are presented in Figure 4. Heat stress at $45^{\circ} \mathrm{C}$ markedly decreased the ATP level in C. oleophila cells (Control vs. Time 0 ). The data from the maltose and lactose treatment were similar. ATP levels were three to four times higher than in the control samples. Additionally, the ATP content in the $10 \%$ sugar treatments was slightly higher than in the 5\% sugar treatments. Collectively, the data indicate that the reduction in ATP levels induced by the high temperature treatment was inhibited by immersing the yeast cells in the sugar solutions, which acted as a protectant.

\section{Biocontrol Efficacy of C. oleophila Exposed to High Temperature}

Fresh cells that were not exposed to high temperatures effectively controlled gray mold caused by $B$. cinerea (Figures $\mathbf{5 A}, \mathbf{B}$ ), blue mold caused by P. expansum (Figures 5C,D), and Alternaria rot caused by $A$. alternata (Figures $5 \mathrm{E}, \mathrm{F}$ ) on apples stored at $25^{\circ} \mathrm{C}$. Disease incidence in control apples that were not inoculated with yeast was $100 \%$. In contrast, disease incidence in apples treated with yeast cells prior to inoculation with a pathogen was lower than the nonyeast controls. However, apples treated with yeast exposed to a high temperature stress while immersed in a sugar solution had a significantly lower disease incidence than apples treated with heat-treated yeast cells that had been immersed in water. Correspondingly, lesion diameters were generally smaller on fruits with fresh and sugar-treated cells than control and heat-treated yeast cells (non-sugar), though the difference was not as apparent as disease incidence. 


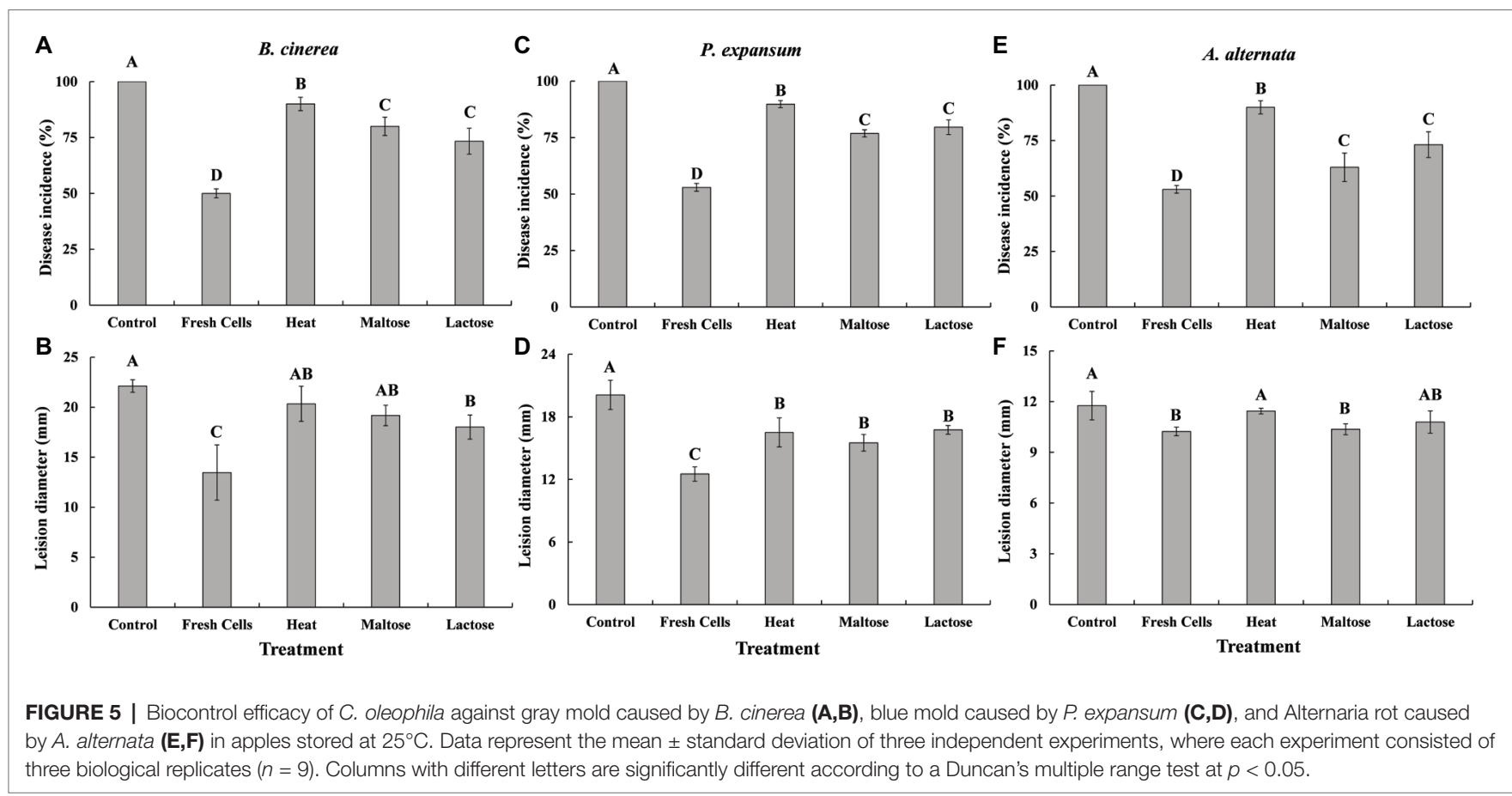

\section{DISCUSSION}

In previous studies, the addition of sugar protectants maintained the viability and biocontrol efficacy of yeast antagonists (Melin et al., 2007; Sui and Liu, 2014; Niu et al., 2016). In the present study, it was clear that the elevated temperature was injurious to yeast cells. Maltose and lactose were effective in improving the tolerance of C. oleophila to high temperature stress $\left(45^{\circ} \mathrm{C}, 10 \mathrm{~min}\right.$ ) (Figure 1). Temperature is an environmental parameter that can have a significant impact on the biocontrol efficacy of antagonistic yeasts used to manage postharvest diseases of fruit crops. Sugars are known to act as protectants against low temperature and high temperature stresses. In the present study, sugar protected the cells from an adverse stress (heat shock), and the adverse stress induced a resistance response that increased the general resiliency of the yeast cells to the conditions found in the wound sites of fruit (primarily osmotic and oxidative stress). In support of this premise, increased resistance to heat and oxidative stress was achieved by exposing biocontrol yeast or bacterial cells to a nonmetabolized, compatible solute, glycine betaine (Cañamás et al., 2007; Liu et al., 2011b; Sui et al., 2012; Zhang et al., 2017). Sugars can also be used as a protective agent in the preparation of liquid and dry formulations of biocontrol yeasts (Stephan et al., 2016). Direct interactions between proteins and the vitrification of sugars are considered to provide a protective mechanism (Sui and Liu, 2014).

Previous reports have demonstrated that heat stress also induces mitochondrial and oxidative damage in cells (Liu et al., 2011a, 2012; Sui and Liu, 2014). The present study demonstrated that ATP levels in C. oleophila cells decreased significantly by the heat treatment, but both maltose and lactose can significantly inhibit the reduction in ATP levels in C. oleophila cells that occur in response to high temperature exposure (Figure 4). Similar results were obtained by Sui and Liu (2014), who found that ATP of the biocontrol yeast, Pichia guilliermondii, decreased at $45^{\circ} \mathrm{C}$, but the decrease trend was slowed down in glucose-treated cells. We speculate that mitochondrial damage caused by heat leads to reduced ATP levels. Mitochondria contain a high level of CAT, which can catalyze the decomposition of hydrogen peroxide into water (Martins and English, 2014). In the present study, CAT activity in maltose- and lactose-treated C. oleophila cells was significantly higher than in the control (Figure 3). GR in cell microsomes can catalyze the reduction of GSSG to GSH, reducing the oxidative levels in cells. TrxR can catalyze the reduction of DTNB by TAD and $\mathrm{NADP}^{+}$by NADPH. The activity of both enzymes has the effect of reducing intracellular ROS levels (Gostimskaya and Grant, 2016). The present study demonstrated that both GR and TrxR in maltose-treated and lactose-treated C. oleophila cells exhibited higher activity than yeast cells in the control group. We suggest that these enzymes play a role in reducing ROS levels induced in the cells in response to heat stress and thus enhance survival. The expression of the corresponding genes to these enzymes was also higher in the sugar-treated cells than control cells (Figure 2) and corresponded to increase in enzyme activity (Figure 3).

The use of yeast antagonists with high viability for postharvest biocontrol is an advantage as competitive for nutrients, and space is one of the basic modes of action in postharvest biological control systems (Wilson and Wisniewski, 1989; Droby et al., 2016). In general, maltose- and lactose-treated C. oleophila cells exposed to a heat stress had lower biocontrol efficacy as fresh 
cells against gray mold, blue mold, and Alternaria rot, but higher efficacy than non-sugar-treated yeast cells exposed to a heat stress (Figure 5). Suspensions of yeasts were prepared to get the same cell numbers, but the percentage of living cells was not the same. Different numbers of living yeasts were applied in each treatment. This could be the cause of the lower biocontrol activity of heat-treated C. oleophila, since living cells are needed to exert the control of pathogens. The disease symptom on fruit host was determined by three bio-factors (pathogen-biocontrol agent-host fruit) of postharvest biocontrol system, and environmental factors (Liu et al., 2013a). In the present study, the differences in the protective effects of C. oleophila against these three different fungal species may be related to specific pathogenicity of each pathogen.

The collective data suggest that maltose and lactose can effectively reduce the oxidative damage that occurs in C. oleophila cells exposed to a lethal high temperature, and as a result, helps to maintain a high viability, survival, and biocontrol efficacy of the yeast. Collectively, the results of the present study demonstrate the ability of maltose and lactose

\section{REFERENCES}

Abadias, M., Benabarre, A., Teixidó, N., Usall, J., and Viñas, I. (2001). Effect of freeze drying and protectants on viability of the biocontrol yeast Candida sake. Int. J. Food Microbiol. 65, 173-182. doi: 10.1016/S0168-1605(00)00513-4

Bradford, M. M. (1976). A rapid and sensitive method for the quantitation of microgram quantities of protein utilizing the principle of protein-dye binding. Anal. Biochem. 72, 248-254. doi: 10.1016/0003-2697(76)90527-3

Cañamás, T. P., Viñas, I., Usall, J., Magan, N., Morelló, J. R., and Teixidó, N. (2007). Mechanisms of glycine betaine enhancing oxidative stress tolerance and biocontrol efficacy of Pichia caribbica against blue mold on apples. Lett. Appl. Microbiol. 45, 6-12. doi: 10.1111/j.1472-765X.2007.02156.x

Chen, X. Y., and Gänzle, M. G. (2017). Lactose and lactose-derived oligosaccharides: more than prebiotics? Int. Dairy J. 67, 61-72. doi: 10.1016/j.idairyj.2016.10.001

Cheng, Z., Chi, M., Li, G., Chen, H., Sui, Y., Sun, H., et al. (2016). Heat shock improves stress tolerance and biocontrol performance of Rhodotorula mucilaginosa. Biol. Control 95, 49-56. doi: 10.1016/j.biocontrol.2016.01.001

Droby, S., Wisniewski, M., Macarisin, D., and Wilson, C. (2009). Twenty years of postharvest biocontrol research: is it time for a new paradigm? Postharvest Biol. Technol. 52, 137-145. doi: 10.1016/j.postharvbio.2008.11.009

Droby, S., Wisniewski, M., Teixidó, N., Spadaro, D., and Jijakli, M. H. (2016). The science, development, and commercialization of postharvest biocontrol products. Postharvest Biol. Technol. 122, 22-29. doi: 10.1016/j. postharvbio.2016.04.006

Gientka, I., Bzducha-Wróbel, A. L., Stasiak-Różańska, L., Bednarska, A. A., and Błażejak, S. (2016). The exopolysaccharides biosynthesis by Candida yeast depends on carbon sources. Electron. J. Biotechn. 22, 31-37. doi: 10.1016/j.ejbt.2016.02.008

Gostimskaya, I., and Grant, C. M. (2016). Yeast mitochondrial glutathione is an essential antioxidant with mitochondrial thioredoxin providing a back-up system. Free Radical Biol. Med. 94, 55-65. doi: 10.1016/j.freeradbiomed.2016.02.015

Ippolito, A., and Nigro, F. (2000). Impact of preharvest application of biological control agents on postharvest diseases of fresh fruits and vegetables. Crop Prot. 19, 715-723. doi: 10.1016/S0261-2194(00)00095-8

Kim, I. S., Kim, Y. S., Kim, H., Jin, I., and Yoon, H. S. (2013). Saccharomyces cerevisiae KNU5377 stress response during high-temperature ethanol fermentation. Mol. Cells 35, 210-218. doi: 10.1007/s10059-013-2258-0

Kim, S. M., Lee, S. M., Seo, J. A., and Kim, Y. S. (2018). Changes in volatile compounds emitted by fungal pathogen spoilage of apples during decay. Postharvest Biol. Technol. 146, 51-59. doi: 10.1016/j.postharvbio.2018.08.003

Li, B., Lai, T., Qin, G., and Tian, S. (2010). Ambient pH stress inhibits spore germination of Penicillium expansum by impairing protein synthesis and folding: a proteomic-based study. J. Proteome Res. 9, 298-307. doi: 10.1021/pr900622j to protect C. oleophila yeast cells against high temperature stress. However, further study on the molecular mechanism involved is needed.

\section{AUTHOR CONTRIBUTIONS}

YS and CZ conceived and designed the experiments. FZ, WZ, $\mathrm{RD}$, and $\mathrm{WY}$ performed the experiments. $\mathrm{FZ}, \mathrm{WZ}, \mathrm{YH}$, and HL analyzed the data. YS and CZ drafted the manuscript. All authors read and approved the final manuscript.

\section{FUNDING}

This work was supported by Natural Science Foundation of Chongqing Science and Technology Commission (cstc2017jcyjAX0401), and Foundation for High-level Talents of Chongqing University of Arts and Sciences (R2016TZ02 and P2017TZ15).

Li, B. Q., and Tian, S. P. (2006). Effects of trehalose on stress tolerance and biocontrol efficacy of Cryptococcus laurentii. J. App. Microbiol. 100, 854-861. doi: $10.1111 / \mathrm{j} .1365-2672.2006 .02852 . \mathrm{x}$

Livak, K. J., and Schmittgen, T. D. (2001). Analysis of relative gene expression data using real-time quantitative PCR and the $2^{-\triangle \triangle C T}$ method. Methods 25 , 402-408. doi: 10.1006/meth.2001.1262

Liu, J., Sui, Y., Wisniewski, M., Droby, S., and Liu, Y. (2013a). Review: utilization of antagonistic yeasts to manage postharvest fungal diseases of fruit. Int. J. Food Microbiol. 167, 153-160. doi: 10.1016/j.ijfoodmicro.2013.09.004

Liu, J., Wisniewski, M., Artlip, T., Sui, Y., Droby, S., and Norelli, J. (2013b). The potential role of $P R-8$ gene of apple fruit in the mode of action of the yeast antagonist, Candida oleophila, in postharvest biocontrol of Botrytis cinerea. Postharvest Biol. Technol. 85, 203-209. doi: 10.1016/j.postharvbio.2013.06.007

Liu, J., Wisniewski, M., Droby, S., Norelli, J., Hershkovitz, V., Tian, S., et al (2012). Increase in antioxidant gene transcripts, stress tolerance and biocontrol efficacy of Candida oleophila following sublethal oxidative stress exposure. FEMS Microbiol. Ecol. 80, 578-590. doi: 10.1111/j.1574-6941.2012.01324.x

Liu, J., Wisniewski, M., Droby, S., Tian, S., Hershkovitz, V., and Tworkoski, T. (2011a). Effect of heat shock treatment on stress tolerance and biocontrol efficacy of Metschnikowia fructicola. FEMS Microbiol. Ecol. 76, 145-155. doi: 10.1111/j.1574-6941.2010.01037.x

Liu, J., Wisniewski, M., Droby, S., Vero, S., Tian, S., and Hershkovitz, V. (2011b). Glycine betaine improves oxidative stress tolerance and biocontrol efficacy of the antagonistic yeast Cystofilobasidium infirmominiatum. Int. J. Food Microbiol. 146, 76-83. doi: 10.1016/j.ijfoodmicro.2011.02.007

Martins, D., and English, A. M. (2014). Catalase activity is stimulated by $\mathrm{H}_{2} \mathrm{O}_{2}$ in rich culture medium and is required for $\mathrm{H}_{2} \mathrm{O}_{2}$ resistance and adaptation in yeast. Redox Biol. 2, 308-313. doi: 10.1016/j.redox.2013.12.019

Melin, P., Håkansson, S., and Schnürer, J. (2007). Optimisation and comparison of liquid and dry formulations of the biocontrol yeast Pichia anomala J121. Appl. Microbiol. Biotechnol. 73, 1008-1016. doi: 10.1007/s00253-006-0552-x

Niu, X., Deng, L., Zhou, Y., Wang, W., Yao, S., and Zeng, K. (2016). Optimization of a protective medium for freeze-dried Pichia membranifaciens and application of this biocontrol agent on citrus fruit. J. Appl. Microbiol. 121, 234-243. doi: $10.1111 /$ jam.13129

Romanazzi, G., Smilanick, J. L., Feliziani, E., and Droby, S. (2016). Integrated management of postharvest gray mold on fruit crops. Postharvest Biol. Technol. 113, 69-76. doi: 10.1016/j.postharvbio.2015.11.003

Spadaro, D., and Droby, S. (2016). Development of biocontrol products for postharvest diseases of fruit: the importance of elucidating the mechanisms of action of yeast antagonists. Trends Food Sci. Tech. 47, 39-49. doi: 10.1016/j. tifs.2015.11.003 
Stephan, D., Silva, A. P. M. D., and Bisutti, I. L. (2016). Optimization of a freeze-drying process for the biocontrol agent Pseudomonas spp. and its influence on viability, storability and efficacy. Biol. Control 94, 74-81. doi: 10.1016/j.biocontrol.2015.12.004

Sui, Y., and Liu, J. (2014). Effect of glucose on thermotolerance and biocontrol efficacy of the antagonistic yeast Pichia guilliermondii. Biol. Control 74, 59-64. doi: 10.1016/j.biocontrol.2014.04.003

Sui, Y., Liu, J., Wisniewski, M., Droby, S., Norelli, J., and Hershkovitz, V. (2012). Pretreatment of the yeast antagonist, Candida oleophila, with glycine betaine increases oxidative stress tolerance in the microenvironment of apple wounds. Int. J. Food Microbiol. 157, 45-51. doi: 10.1016/j.ijfoodmicro.2012.04.010

Sui, Y., Wisniewski, M., Droby, S., and Liu, J. (2015). Responses of yeast biocontrol agents to environmental stress. Appl. Environ. Microbiol. 81, 2968-2975. doi: 10.1128/AEM.04203-14

Vilanova, L., Vall-Llaura, N., Torres, R., Usall, J., Teixidó, N., Larrigaudière, C., et al. (2017). Penicillium expansum (compatible) and Penicillium digitatum (non-host) pathogen infection differentially alter ethylene biosynthesis in apple fruit. Plant Physiol. Biochem. 120, 132-143. doi: 10.1016/j.plaphy.2017.09.024

Wang, Y., Luo, Y., Sui, Y., Xie, Z., Liu, Y., Jiang, G., et al. (2018). Exposure of Candida oleophila to sublethal salt stress induces an antioxidant response and improves biocontrol efficacy. Biol. Control 127, 109-115. doi: 10.1016/j. biocontrol.2018.09.002
Wilson, C., and Wisniewski, M. (1989). Biological control of postharvest diseases of fruits and vegetables: an emerging technology. Annu. Rev. Phytopathol. 27, 425-441. doi: 10.1146/annurev.py.27.090189.002233

Wilson, C., Wisniewski, M., Droby, S., and Chalutz, E. (1993). A selection strategy for microbial antagonists to control postharvest diseases of fruits and vegetables. Sci. Hortic. 53, 183-189. doi: 10.1016/0304-4238(93)90066-Y

Zhang, X., Zhang, G., Li, P., Yang, Q., Chen, K., Zhao, L., et al. (2017). Mechanisms of glycine betaine enhancing oxidative stress tolerance and biocontrol efficacy of Pichia caribbica against blue mold on apples. Biol. Control 108, 55-63. doi: 10.1016/j.biocontrol.2017.02.011

Conflict of Interest Statement: The authors declare that the research was conducted in the absence of any commercial or financial relationships that could be construed as a potential conflict of interest.

Copyright (c) 2019 Zheng, Zhang, Sui, Ding, Yi, Hu, Liu and Zhu. This is an open-access article distributed under the terms of the Creative Commons Attribution License (CC BY). The use, distribution or reproduction in other forums is permitted, provided the original author(s) and the copyright owner(s) are credited and that the original publication in this journal is cited, in accordance with accepted academic practice. No use, distribution or reproduction is permitted which does not comply with these terms. 